\title{
MULTIPLE-UNIT IMPLANT FRAMES: ONE-PIECE CASTING VS. LASER WELDING AND BRAZING
}

\author{
SOBRE ESTRUTURAS DE IMPLANTES MÚLTIPLOS: FUNDIÇÃO EM MONOBLOCO \\ VERSUS SOLDAGEM A LASER E BRASAGEM
}

Elza Maria Valadares da COSTA ${ }^{1}$, Maximiliano Piero NEISSER ${ }^{2}$, Marco Antônio BOTTINO ${ }^{3}$

\author{
1- DDS, MSc, PhD Student of the Department of Prosthodontics and Dental Materials - UNESP, Dental School, São José dos Campos, São \\ Paulo, Brazil. \\ 2- DDS, MSc, Department of Prosthodontics and Dental Materials - UNESP, Dental School, São José dos Campos, São Paulo, Brazil. \\ 3- DDS, MSc, PhD Professor Department of Prosthodontics and Dental Materials - UNESP, Dental School, São José dos Campos, \\ São Paulo, Brazil.
}

Corresponding address: Dra Elza Maria Valadares da Costa - Rua: Emílio Lang Junior, 86 Jardim da Saúde/ São Paulo - SP/Brazil Cep.: 04291-050 Office phone number: (55) 11 3884-7370/ E-mail: elzavala@greco.com.br

Received: January 06, 2004 - Returned for modification: March 03, 2004 - Accepted: May 27, 2004

\begin{abstract}
$T_{\mathrm{r}}$

The linear distortion of prostheses over implants, one-piece casting and cast in sections followed by laser welding by laser and brazing was evaluated in an edentulous mandibular model with five parallel abutments, with a distance of $10 \mathrm{~mm}$ from center to center. Seventy five gold cylinders were tightened with screws on the abutments with $10 \mathrm{Ncm}$ torque. The cylinder/analogue assemblies were measured by microscopic examination $(0.001 \mathrm{~mm}$ accuracy) and the obtained results were compared with the GC (control group). Fifteen metal frames were waxed and cast in a gold alloy (Stabilor, Degussa Hulls, Brazil) and divided into three groups with five elements each, as followed: GM (one-piece casting), GB (section and brazing) and GL (section and laser welding). In all groups, measurements were taken at the right, left, buccal and lingual sides of the cylinder/analogue interface and the results were submitted to analysis of variance (ANOVA) and to the Tukey test (5\%). The smallest amount of distortion was seen in the laser group (GL with a mean value of 13.58), followed by the brazing group (GB with a mean value of 24.33) and one-piece (GM with a mean value of 40.00). The greatest distortion was found in the one-piece group (GM).

Uniterms: Implant prosthesis; Endosseous dental implants; Welding.
\end{abstract}

\section{RESUMO}

A

distorção linear das próteses sobre implantes, fundidas em monobloco e fundidas em secções e soldadas a laser e por brasagem foi avaliada em um modelo de uma mandíbula edêntula com cinco análogos de pilares de implantes, paralelos entre si com distância de $10 \mathrm{~mm}$ medidos de centro a centro. Sobre estes foram parafusados novos cilindros de ouro, com torque de $10 \mathrm{~N} / \mathrm{cm}$. Então foram executadas 15 sobre-estruturas metálicas que foram divididas: GC - Adaptação passiva dos cilindros de ouro; GM - monobloco, GB - segmentos soldados por brasagem e, GL - segmentos soldados a laser. Observaram-se as estruturas fixadas com parafusos novos sob microscópio de mensuração. A medição foi realizada na vestibular direita e esquerda e da mesma forma na lingual da interface cilindro/análogo e dados anotados em tabela apropriada. Para o eixo y, a técnica de soldagem a laser (Média=12,41 e $\mathrm{Dp}=11,12$ ) produziu menos distorção significativamente do que a técnica de brasagem (Média=23,06 e $\mathrm{Dp}=21,88$ ) seguida pela técnica de monobloco (Média=39,83 e $\mathrm{Dp}=21,88$ ) $\mathrm{p}=0.05$. Para o eixo $\mathrm{x}$, somente o grupo Monobloco apresentou diferença significativa para as demais técnicas (Média=45,66 e Dp=21,56).

Unitermos: Implante sobre prótese; Implante dentário endoósseo; Brasagem.

\section{INTRODUCTION}

Multiple-unit splinted implant superstructures require more accuracy than those on natural teeth due to the absence of periodontal tissues that, according to Brunski and Skalak²(1993), compensate for small errors between the abutments and the prosthetic components. Thus, according to Adell, et al. ${ }^{1}$ (1981), Skalak ${ }^{11}$ (1983), Sjögren, et al. ${ }^{10}(1988)$ 
and Rangert, et al. ${ }^{7}(1989)$ the clinical success of implants after placement of the prostheses can be predicted if there is a passive fit between the metallic structure and the implant abutments.

Adell, et al. ${ }^{1}(1981)$, Skalak $^{11}(1983)$, Brunski and Skalak$^{2}$ (1993), Jemt and Lie'(1995) and Romero, et al. ${ }^{8}(2000)$ associated problems originated by the poor fit of prosthetic structures supported by implants to mechanical problems, such as loss or loosening of screws, fractures of the prosthetic structures and of the implant components, and also implant failure due to excessive bone loss.

The misalignment of the fixed prosthesis in relation to implants will originate internal stresses in the implants and bone. These stresses cannot be detected by visual inspection, but they can reduce the threshold of factors responsible for failures of implants or prostheses, regardless of external forces such as occlusion.

Therefore, the factors that can directly influence the prosthesis fit lie in the building technique of the metal frame. There are two technical possibilities: casting in a single piece or in parts to be welded later. According to Chai and Chou ${ }^{4}$ (1998), the welding technique has the advantage of working with segments, besides allowing a better fit, uniform distribution of forces, minimizing of trauma, either on natural teeth and implants.

Due to the importance of an accurate fit between the metal frames and multiple implants, the proposal of this research was to evaluate the linear distortion of prosthetic metal frames on osseointegrated implants. Three types of frames were studied: 1) one-piece casting, 2) sectioned casting followed by laser welding, 3) casting followed by brazing.

\section{MATERIALAND METHODS}

Five 4.0-mm wide standard abutment implant cylinder analogues [A, B, C, D, E] were installed and fixed with transversal screws in a metallic block similar to an edentulous mandibular arch. (STDCB 175-0 Nobel Biocare do Brasil Ltda). The distance between the analogues was $10 \mathrm{~mm}$ from center to center (Figure 1). Standard gold alloy cylinders (Conexão Ltda, Brazil) were connected to the abutments and fixed to these analogues with gold screws, using a $10-\mathrm{Ncm}$ torque.

To obtain the standard frames, a 3.0-mm cross section wax cylinder (Slaycris, USA) was sectioned and adapted to the gold cylinders, with two 3.0-mm distal extensions (cantilevers). To standardize the frames, an impression was made (Elite Double - Zhermack, Italy) from the standard frame in wax . This mold was installed on the master cast with the screw-retained gold cylinders and filled with wax to form the patterns (Slaycris, EUA). After cooling, they were taken off the model and the screws were removed from the analogues. This procedure was repeated until 15 similar wax frames were obtained, which were divided into three groups with five elements each, named: GM (one-piece casting), GB (brazing) and GL (laser).
In the GB group, each pattern was cast in five segments and subsequently assembled by brazing; the wax frames were sectioned with an acetate blade (0.25-mm wide). Brazing is the method of welding by addition of a metal with lower melting point than that of the base metal, the joint being filled by capillary effect. The welded joint can be defined as the area where the union of two metallic parts takes place, with or without any addition of metal using a source of heat.

In both groups, the sections were performed on the wax frame separated from the mandibular master cast, to avoid an increase in the width of the obtained spaces. If the wax frame was sectioned on the master cast with screw-retained gold-cylinders, that would cause tension between them and an increase in the spaces. All cuts were symmetrical with the gold cylinder in the center of the segment.

The waxed patterns were placed in welding investment (Hi-heat, Polidental, Brazil) and cast in a gold alloy (Stabilor G - Degussa-Hülls, Germany) with 58\% Au, 5.5\% Pt and $23.3 \% \mathrm{Ag}$, between $860-940^{\circ} \mathrm{C}$.

The cast segments were connected on the master cast with self-curing acrylic resin (Duralay Reliance Dental M/g, Co. Worth III-USA) (Figure 1). After 24 hours, they were invested (Hi-heat, Polidental, Brazil) and the resin was eliminated. These segments were then assembled by brazing with a gas torch (Record) $\left(\mathrm{O}_{2}\right.$ /air) and solder (Degulor 2; Degussa Hülls).

In the GL group, each pattern was cast in five segments and subsequently assembled by welding; the wax frames were sectioned with a $0.1-\mathrm{mm}$ wide shaving blade (Gillette do Brasil Ltda.). The segments were installed and tightened on the master cast using a torque moment of $10 \mathrm{Ncm}$ and connected with resin as for group GB. After curing the resin, the specimens were connected to analogues, and five models were prepared (type IV stone -Durone - Dentsply, Brazil), one for each structure to be welded. The connection was made with a laser welding device (Dentaurum DI 2002 S/ SFS, model Desk top-Germany) according to the device manufacturer's protocol: 325V, 5.20KW, $14 \mathrm{~ms}$ pulses and $3.71 \times 10^{5} \mathrm{~J}$ welding power.

The fit was examined in all cylinders (groups GM, GB, GL) and connected to the mandibular master cast with new gold screws $(10 \mathrm{Ncm})$ to avoid pre-load changes due to lengthening of their threads (Brunski and Skalak² 1993). The

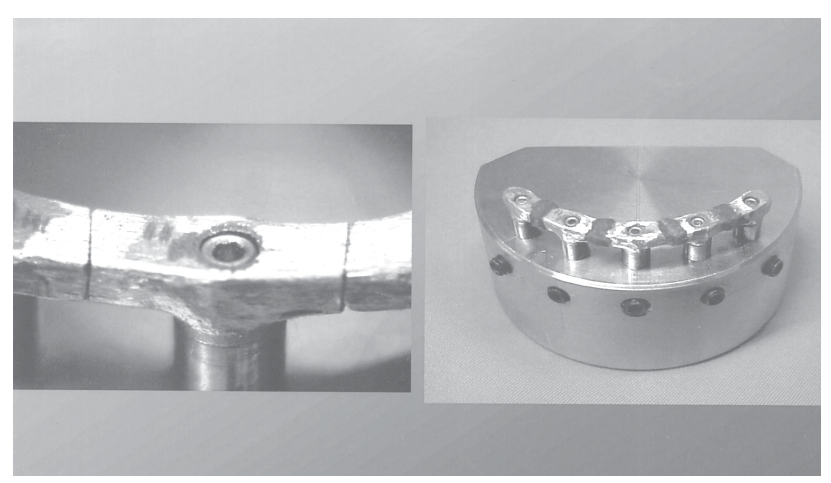

FIGURE 1- Space for welding and connection of segments with resin on the master cast 
control group (GC) was formed by 25 individual gold cylinders connected by screws to the analogues. A measuring microscope (OLYMPUS STM, Japan) with an auxiliary reading unit (MMDC 201 for axes $\mathrm{x}$ and y), with $0.001 \mathrm{~mm}$ accuracy and 30x magnification was used to read the values of dimensional alterations that represent the fit between the prosthetic components (gold alloy cylinders) and the abutment analogues.

To obtain all measures, a reference point was always considered on the abutments analogues on the mandibular master cast. On the $\mathrm{x}$ axis, to the horizontal alignment of the analogues to the gold cylinders of the frame was given the value zero in the auxiliary reading unit. When the gold cylinder was to the left or right of the analogue, another value was registered. On the y-axis, the vertical alignment of the analogue to the gold cylinder was considered the starting point for all readings.

These measurements (fit of gold cylinders to the analogues) were taken on the buccal, lingual, mesial and distal sides of each cylinder [A, B, C, D, E]. Thus, four measurements were obtained for each cylinder/analogue connection, to a total of twenty measurements for each frame. The measurements were taken three times and an arithmetical mean value was obtained. All measurements could be placed on the $\mathrm{x}$ (horizontal) and $\mathrm{y}$ (vertical) axes (Figure 2).

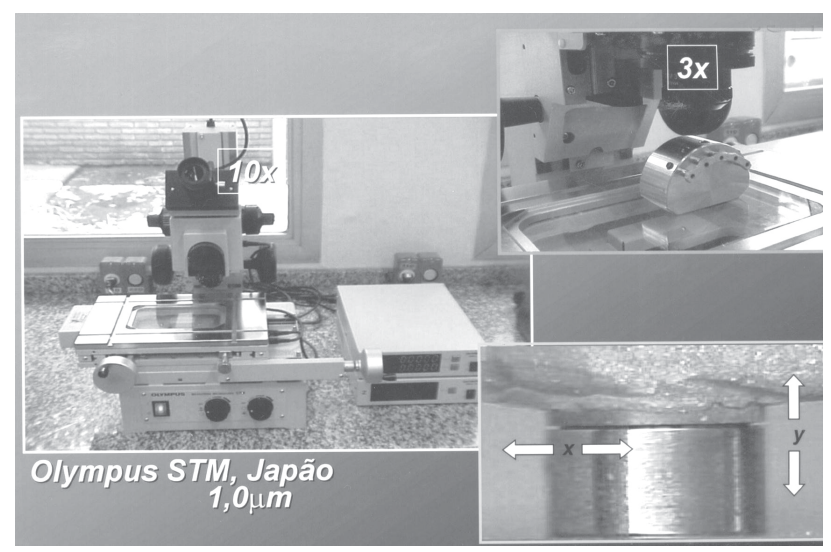

FIGURE 2- Microscope employed to take the measurements of the fit of full-arch fixed prostheses to the master cast on the $x$ and $y$ axes

\section{RESULTS}

The results and statistical analysis of the techniques (one-piece casting, brazing and laser) and of the control group on axes $\mathrm{x}$ and $\mathrm{y}$ are described on Table 1 and graphically illustrated (Figure 3).

It can be seen that on the y axis (vertical), all techniques had differences between themselves and in relation to the control group. On the $\mathrm{x}$ axis (horizontal), only the one-piece casting technique showed a statistically significant difference (greater misfit) in relation to the three other groups: brazing, laser and control, at a confidence interval of 5\%.

\section{DISCUSSION}

Several authors have described the importance of a passive fit between frames and osseointegrated implants. $\mathrm{Goll}^{5}$ (1991) recommends the use of machined prosthetic parts (gold alloy cylinders) to guarantee better contact between the abutment and the cylinder; for this reason, machined prosthetic parts were used in this research. This may explain why the control group presented values of misfit.

No significant difference was found between the control and laser groups, probably because laser welding is a process whose peculiarity is its concentrated source of heat, generating a smaller heat-affected zone in the metal and causing minor distortion (Souza, et al. ${ }^{12}$, 2000). Furthermore,

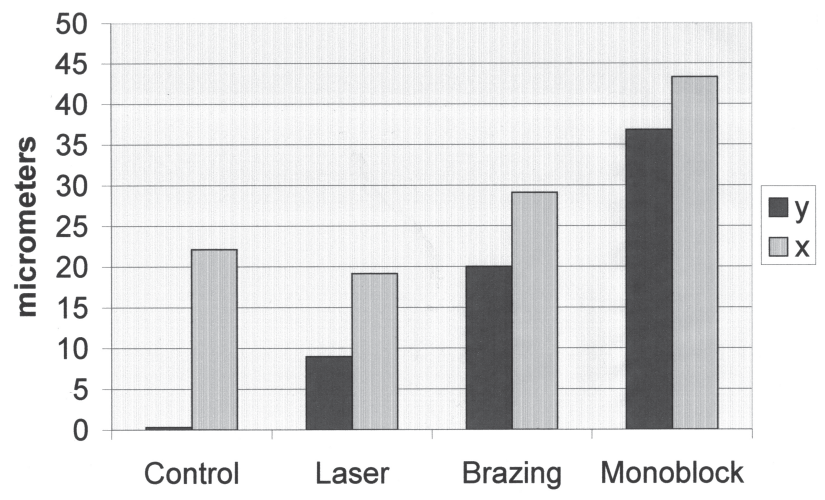

FIGURE 3- Graphic representation on $x$ and $y$ axes of the mean values for the techniques and control group

TABLE 1- Mean values ( $\mu \mathrm{m})$ and standard deviation (control group, one-piece casting, brazing and laser welding)

\begin{tabular}{lccrr}
\hline Techniques & $\begin{array}{c}\text { X axis } \\
\text { Mean values }\end{array}$ & Standard deviation & $\begin{array}{c}\text { Y axis } \\
\text { Mean values }\end{array}$ & Standard Deviation \\
\hline Control & 22.609 & 6.772 & 1.444 & 3.177 \\
Laser & 21.007 & 13.763 & 12.413 & 11.129 \\
Brazing & 30.729 & 14.220 & 23.065 & 13.314 \\
Monoblock & 45.664 & 21.568 & 39.831 & 21.887 \\
\hline
\end{tabular}


the differences on the $\mathrm{x}$ axis (horizontal) between the gold cylinders and analogues of the control group may have been caused by the problems inherent to manufacturing process of these components.

Skalak ${ }^{11}$ (1983) studied through mathematical models the biomechanics of osseointegrated prostheses and the need of avoiding stress forces between the implant and the bone, which might result in bone resorption and progressive implant loss. He stated that any misfit of the prostheses in relation to the implants will originate internal stresses in the prostheses, implants and bone, and that a rigid and accurate connection between prostheses and implants is needed for the success of the implant-supported prostheses. A rigid connection between the fixed prostheses and implants seems more viable when the frame is cast in segments and assembled by laser welding as shown in this study.

Brunski and Skalak² (1993) have shown that, when the gold screw is tightened when there is a misfit, the stress forces that act on the screw will originate a force that brings the gold cylinder towards the abutment, decreasing the space. If this space if small, it might be totally closed by the frame deformation. However, if it is large, it will not close and the implants will receive a greater load. In this study, the spaces between frames and abutments were measured after the gold screws were tightened (10Ncm), according to the above-mentioned authors. Also, according to those authors, when the gold screw is tightened on the abutment using a torque moment of $10 \mathrm{Ncm}$, it originates tension in the screw and compression in the cylinder. These forces, equivalent and opposed, keep the structure closed (preload).

Carr, et $a^{3} .^{3}$ (1996) found no difference in the osseointegrated interface when examining the bone level around the implants. A structure was examined in a microscope connected to a computer by an image analysis program, in frames with two different fits, good $(38 \mu \mathrm{m})$ and poor $(345 \mu \mathrm{m})$. According to this study, good or poor fit had no influence on the osseointegrated interface. However, this research is limited by the small number of samples (10 implants in the group with good fit and 11 implants in the group with poor fit) and by the lack of clinical simulation, as the implants received no occlusal load.

Waskewicz, et al. ${ }^{13}$ (1994) compared frames supported by five implants with passive fit (cut in segments and welded) and non-passive fit (one-piece casting) by means of photoelastic analysis. After tightening the screws on the abutments, the authors observed the stress patterns generated around the implants of the frame with nonpassive fit. These stress patterns were greater than those found in the frame with passive fit. In this case, there were no stress patterns around the implants.

Weinberg ${ }^{14}$ (1993) explains that the implant/abutment/ prosthesis interface introduces minimum degrees of flexibility by deformation of the gold retention screw (deformation limit of $100 \mu \mathrm{m}$ in the vertical direction), and that these undergo more deflection than the prosthetic structure.

Schiffleger, et al. ${ }^{9}$ (1985) and Brunski and Skalak² (1993) agree that distortion in fixed prostheses increases with the number of elements. Moreover, fixed prostheses with more than three elements are more precise when connected by welding than when fabricated as one-piece castings. This statement agrees with this study: frames with five abutments placed on implants showed less distortion when the frames were cast in sections followed by laser welding or brazing than when the frames were cast in one piece.

Jemt and Lee ${ }^{6}$ (1995), in a three-dimensional photographic technique distortion study of prostheses, supported by five implants in the lower arch, with the frame cast in one-piece, found greater distortion of the cylinders in the horizontal plane. In the mandible, the mean 3D (three-dimensional) angular distortion of the cylinders was $51 \mu \mathrm{m}$ (standard deviation 35) and the mean 3D distortion of the central point was $74 \mu \mathrm{m}$ (standard deviation 38). These values are greater than those found in this study, with a mean of $40 \mu \mathrm{m}$ (standard deviation 21) in the same axis. This study used optical observation $(0.001 \mathrm{~mm}$ precision digital measuring microscope) only on the $\mathrm{x}$ and $\mathrm{y}$ axes. The authors noticed a significant correlation between frame curvature and distortion; the greater the curvature, the greater was the distortion. In this study. the arch angle of the mandibular master cast was fixed in $112.5^{\circ}$, the mean angle of the human mandible between the mental foramina (Brunski and SkalaK ${ }^{2}$ -1993). The authors mentioned that, when implants and standard abutments are parallel, a certain misfit might be acceptable, within the tolerance of the machined prosthetic components, without originating stress during frame connection. On the other hand, systems that use conical abutments imply on more problems of horizontal distortion with similar fit and stress. The master cast used in this study has parallel standard abutments, simulating an ideal situation.

Romero, et al. ${ }^{8}$ (2000) analyzed three methods, section and welding of the same alloy, section followed by brazing. and section followed by two cycles of electrical discharge, to correct frames cast in one-piece, accepting as passivity a misfit of up to $10 \mu \mathrm{m}$. They built frames on only two abutments and the measurements of misfit were taken on the $y$ axis (mesial, distal and lingual) in the measuring microscope while only the right abutment was tightened with a torque of $15 \mathrm{Ncm}$. In the "correction through brazing" group, the authors found a mean value of $72 \mu \mathrm{m}$ and, in this study, a mean value of $23 \mu \mathrm{m}$ was found on the $y$ axis in the brazing group. Perhaps this lower value is due to the fact that these measures were taken with all cylinders tightened with screws. The assembling by brazing was not a corrective procedure in this case. In this study, the mean distortion found on the $y$ axis for the laser group was $12.413 \mu \mathrm{m}$, a value near to the passivity standard advocated by these authors $(10 \mu \mathrm{m})$.

Dentistry has employed the brazing process with gas/ air blowtorch, known as conventional welding, due to the low cost and technical simplicity, being the most used in prosthesis laboratories. The laser welding process can be employed to weld a wide variety of metals, due to the coherent monochromatic, focused and the high-energy light beam, without causing substantial distortion to the 
prosthetic frame.

Souza et al $^{12}$ agree that the process of brazing transfers great welding energy to the piece to be welded, generating a greater heat-affected zone - HAZ - in the metal and causing more distortion problems to the pieces. The laser welding is a process that minimizes such problems.

The present study has indicated that the routine clinical implant cases may present a distortion of the prostheses relative to the master casts. According to the results of this study and in comparison with other papers in the literature that mention the advantages of welding by brazing, it is reasonable to conclude that welding by laser is feasible to replace other techniques, mainly when used in prostheses supported by several abutments, on which a passive fit is hard to achieve.

\section{CONCLUSIONS}

a) On the $x$ axis (horizontal), the lowest distortion values were seen in the laser group, statistically similar to the brazing group and the control group. The group cast in one piece showed the worst results, statistically different from the others groups.

b) On the y axis (vertical), the lowest distortion values were seen in the control group, followed by laser, brazing and one-piece casting group; all values were statistically different between themselves.

\section{ACKNOWLEDGEMENTS}

The generous help and assistance of Luis Kian in the laboratorial phase of the study is highly appreciated.

\section{REFERENCES}

1- Adell R; Lekholm U, Rockler B, Branemark, PI. A 15-years study of osseointegrated implants in the treatment of the edentulous jaw. Int J Oral Surg 1981;10:387-416.

2- Brunski JB, skalak, R. Biomechanics of osseointegration and dental prostheses. In Naert, I.; Steenberg, D.V.; Worthington, P. Quintessence Osseointegration in oral reabilitation; 1993. p.133-56.

3- Carr AB, Gerard DA, Larsen PE. The response of bone in primates around unloaded dental implants supporting prostheses with different levels of fit. J Prosthet Dent 1996; 76:500-9.

4- Chai T, Chou CK. Mechanical properties of laser welded cast titanium joint under different conditions. J Prosthet Dent 1998; 70:477-83.

5- Goll GE. Production of accurately fitting full arch implant frameworks: part I - Clinical procedures. J Prosthet Dent 1991; 66:373-84.

6- Jemt T, Lie A. Accuracy of implant supported prosthesis in the edentulous jaw. Clin Oral Impl Res 1995; 6:172-80.

7- Rangert B, Jemt T, Jorneus L. Forces and moments on Branemark implants. Int J Oral Maxillofac Implants 1989; 4:241-7.
8- Romero GG. Accuracy of three correct techniques for implant bar fabrication. J Prosthet Dent 2000; 84:602-7.

9- Schiffleger B, E Ziebert, G J, Dhuru, V B, Brantley W A, Sigaroudi K. Comparison of accuracy of multiunit one-piece castings. J Prosthet Dent 1985; 54:770-6.

10- Sjögren G, Anderson M, Bergman M. Laser welding of titanium in dentistry. Acta Odontol Scand 1988; 46:247-53.

11- Skalak, R. Biomechanical considerations in osseointegrated prostheses. J Prosthet Dent 1983; 49:843-8.

12- Souza PCRD; Dinato, JC; Bottino, MA; Guastaldi, AC. Brasing and laser welding of a Ni-Cr alloy.Pós Grad Rev Fac Odontol São José dos Campos, 2000, 3:7-16.

13- Waskewicz G.A, Ostrowski JS, Parks VJ. Photoelastic analysis of stress distribution transmitted from a fixed prosthesis attached to osseointegrated implants. Int J Oral Maxillofac Imp 1994; 9:40511 .

14- Weinberg L. The Biomechanics of force distribution in implant supporting prostheses. Int J Oral Maxillofac Imp 1993; 8:19-31 